\title{
The residential energy futures of Bhutan
}

\author{
Kinley Zam (iD) - Mukesh Kumar Gupta • \\ Sayed Mohammad Nazim Uddin
}

Received: 2 February 2020 / Accepted: 3 March 2021 / Published online: 6 April 2021

(C) The Author(s), under exclusive licence to Springer Nature B.V. 2021

\begin{abstract}
It is expected that with the increase in population and modernization of any country, energy consumption would increase. Bhutan is a carbonnegative country and committed to remaining carbon-neutral. Thus, identifying energy-saving potential will increase energy efficiency and contribute to continue fulfilling this pledge for years to come. This study aims to find the energy-saving potential of Bhutan by analyzing future energy demand from the residential building sector using a scenario-based modeling tool called Long-range Energy Alternatives Planning (LEAP). The research was an integration of primary and secondary data calculations. Final energy-savings from Bhutan in 2040 by attaining the efficient scenario is estimated at 830 GWh. Overall, the result suggests that $53 \%$ final energy-savings can be achieved in 2040 from all end-uses and energy sources compared to the reference scenario. Cumulatively, 19 TWh final energysavings can be achieved in the study period (20182040) from the efficient scenario while all basic energy needs are fully met in 2040. This result obtained would provide a reference for Bhutan's future energy planning and guidelines for policymaking. It would also provide policy recommendations about the scope of shifting to energy-efficient end-uses.
\end{abstract}

K. Zam $(\bowtie) \cdot$ M. K. Gupta • S. M. N. Uddin Asian University for Women, 20/A M.M. Ali Road, Chittagong 4000, Bangladesh

e-mail: kinleyzamr@gmail.com
Keywords Urbanization · Energy Consumption · Energy Savings $\cdot$ Energy Services $\cdot$ Scenario Analysis

\section{Introduction}

Bhutan is a small developing country, and tremendous changes have been seen in the energy demand in the last few decades. The residential sector accounts for $33 \%$ of the total energy consumption of 650,220 tons of oil equivalent (IRENA, 2019). Energy sources used for lighting, cooking, heating, and appliances have changed over the years. In Bhutan, traditionally, biomass has been the principal source of energy and accounted for $91 \%$ of total resident energy use in 2005 . Over the last 5-10 years, the energy usage pattern has changed drastically, switching to more modern fuels like electricity and LPG from traditional fuels like biomass (Lhendup et al., 2010). In 1967, with Bhutan's first hydroelectric plant of $360 \mathrm{~kW}$ installed, only Thimphu, the capital, received a power supply (Tshering and Tamang, 2004). By 2017, almost $100 \%$ of households in the country use hydro-electricity for lighting replacing wood, kerosene lamps, and others (NSB, 2017).

Similarly, the data reports changes in energy sources for cooking and heating. In 2007, a high percentage of household $(40.7 \%)$ used firewood for cooking, followed by electricity (34.2\%) and LPG (22.6\%) (NSB, 2007). The Bhutan Living Standards Survey 2017 states that, for cooking, two main energy sources were taken into account since many households use more than one source. The percentage using LPG raised to $71 \%$ and 
electricity, 94.9\%. For heating, bhukhari (wood), electric heater, and traditional stove (wood) are used at present (NSB, 2017). Continuing use of inefficient energy would increase carbon and other greenhouse gases. Thus, finding energy-saving potential to increase energy efficiency would contribute to fulfilling this pledge.

Bhutan committed to remaining carbon-neutral in 2009 and reiterated its commitment to remain carbon-neutral during COP 21 in 2015. Currently, forests cover $70.46 \%$ of Bhutan's total land area, and sequestration by forest is estimated at 6.3 million tons of $\mathrm{CO} 2$; emissions in 2013 are estimated at 2.2 million tons of $\mathrm{CO} 2$ equivalent (NEC, 2015). To remain carbon-neutral, pursuing low emission development pathways across all sectors is important. One of the ways to mitigate is by promoting energy efficiency. Finding energy-efficient methods would help in the betterment in terms of energy. This is because of the growing population and availability of new appliances due to development increases energy consumption.

The population of Bhutan in 2017 was estimated to be 692,895 and the total number of households was 164,011 (NSB, 2017). There is a population growth rate of $1.3 \%$ per annum between 2005 and 2017 (NSB, 2017).

This study aims to find energy-saving potential in the residential building sector in Bhutan by analyzing future trends of energy demand under different scenarios. Although few studies have been done on domestic energy consumption patterns in Bhutan, energy consumption projection and finding energy-saving potential, which is done in this research, are the first of its kind in the country. The study also aims to fill this research gap in knowledge by providing evidence-based energy-efficient pathways to provide an energy-efficient perspective that may help governments, policy-makers, and organizations choose and prepare for the desired future. Policy-making in the energy sector is strongly influenced by models designed to predict the effects of policies on energy demand, economic output, and energy-related pollution (Proença and Aubyn, 2009).

The study was done using a scenario-based modeling tool called Long-range Energy Alternatives Planning (LEAP), a widely used software tool developed by Stockholm Environment Institute which assists in energy policy analysis and climate change mitigation assessment (LEAP, 2018). It is an integrated modeling tool: on the demand side, these range from bottom-up, end-use accounting techniques to top-down macroeconomic modeling. Scenario analysis using LEAP has helped in providing policy recommendations in many countries. In Nepal, household energy use was analyzed based on the LEAP framework, and the paper recommended emphasizing the reduction of biomass for cooking and promote domestic alternative energy sources (Malla, 2013). LEAP model was also used to study energy policy for low carbon development in Nigeria. The study found that the Nigerian government's policy intervention, as in the green optimistic scenario, would lead to a decrease in energy demand (Emodi et al., 2017). Africa's energy future was also modeled using LEAP. The study provided some policy insights and identifies synergies and trade-offs relating to energy policies' potential to promote universal energy access and enable a transition to renewable energy (Ouedraogo, 2017). Thus, scenario analysis helps in policy recommendation.

The study uses a bottom-up approach, i.e., calculating final energy demand by end-use on the level of individual households and aggregating these figures to the whole population. This modeling tool has been adopted by thousands of organizations in more than 190 countries worldwide. LEAP is used because it has low initial data requirements. Many modeling tools have constraints such as the requirement of highly inflexible data and a high level of expertise. In contrast, LEAP allows users to start energy modeling with a relatively simple accounting principle. Since Bhutan currently has limited data in the energy sector, LEAP is used. In this study, LEAP projected energy demand from 2018 to predict values for different years up to 2040 under three scenarios: current scenarios (base year), reference scenario, and efficient scenario.

Although precise estimates of saving potentials could not be found, the objective of this study is to give a general idea of the magnitude of energy-saving potential in the residential sector of Bhutan. There are some assumptions made in the study. The energy consumption from each appliance depends on its size, type, and use. In this research, a single representative size and a single representative type (the most common type and size for each appliance) are identified for each appliance based on their primary use. Other studies have also used common types and sizes for each appliance (Gupta, 2017; Duan et al., 2019). The Developing the Electricity Demand Model for Iran's Residential Sector; Based on LEAP used average daily usage time of most common electrical appliances in urban and rural Iranian households entered into the model (Moradi, 2013).

However, it is expected that this simplification will not seriously bias the analysis results because the impact 
will be offsetting to some extent. For example, larger savings from bigger appliances will be offset by smaller savings from smaller appliances (Gupta, 2017). Thus, the total energy-saving will be approximately the same.

The end-uses covered in the analysis are lighting, cooking, space heating, water heating, and appliances. For cooking, energy sources used are electricity, LPG, wood fuel, kerosene, dung cake, and biogas. For lighting, end-uses considered are incandescent, fluorescent, CFL, LED bulbs, and tube lights. For space heating and water heating, electricity and wood fuel are used. Appliances that are considered are fans, television, and refrigerator.

The results obtained from the study would provide a reference for Bhutan's future energy planning and guidelines for policy-making. It would also provide suggestions for energy conservation.

Shifting from the use of fuelwood to renewable energy sources like hydropower and alternative renewable sources would enhance energy efficiency and reduce biodiversity loss and impact human health.

\section{Methodology}

This research includes energy forecasting and finding the energy-saving potential of Bhutan. This is done by predicting values for different years, up to 2040 under three scenarios: current scenario (base year), reference scenario, and efficient scenario using a scenario-based modeling tool called Long-range Energy Alternatives Planning (LEAP). One of the main reasons to use LEAP is that it represents developing countries' characteristics and economies very well (Bhattacharya and Timilsina, 2009; Urban et al., 2007). LEAP modeling has been used for long-term energy demand forecasting of regions with limited statistical data (Chen et al., 2019). Long-term electricity demand forecast and supply-side scenarios for Pakistan (2015-2050) are also done using LEAP (Mirjat et al., 2018).

The integration of primary and secondary data has been used in the calculations. Most of the data used for the study are secondary data from the National Statistical Bureau's Bhutan Living Standard Survey Report 2017 which has the nation's data on population, household size, gender, type of dwelling, and percentage of households using different sources of energy for heating, cooking, lighting, and appliances (television, refrigerator).
However, there is no recorded data on the use of fuel intensity by households. Thus, to calculate the energy consumption intensity, primary data is collected by representative sampling from 60 households in Thimphu and Punakha districts (western part of Bhutan) in July 2018. The bottom-up approach, like LEAP, extrapolates the estimated energy consumption of a representative set of individual houses to the regional and national levels (Swan and Ugursal, 2009). A quantitatively designed survey questionnaire was used to collect information on energy consumption. Primary data collection areas are representative of the nation, as Thimphu represents areas that are cold in winter and require a heating system. Punakha represents hot areas that require fans in summer. The participants include different dwelling types present in the country, like mud-bonded bricks or stone-walled dwellings, houses with cement-bonded bricks or stone-walls, and houses with concrete walls and wood walls. The questionnaire contained a large list of questions about the type of energy sources, type of end-uses, the quantity of fuel use, and power consumption (watt*hours/day). Using Microsoft Excel 2010, the above information has been used to calculate average energy consumption per household. The details of the calculations are given in the annexure.

The reference scenario forecasts the country's energy demand in the absence of additional policies beyond what is already planned. Next, the efficient scenario is created by introducing efficient appliances and forecasting energy demand until 2040. Comparing the two scenarios, energy-savings from the transition from reference to an efficient energy system are obtained. Then, the overall final energy demand and savings are calculated. To check the validity of the results, calibration in the base year is carried out.

LEAP data structure for the energy demand analysis

The first step for energy analysis in LEAP is designing a data structure. The data structure determines the kind of technologies and alternative scenarios that can be analyzed. The data structure is adapted based on the availability of data, the types of analyses, and unit preferences. Sector (household), end-uses (cooking, lighting, space heating, water heating, and appliances), and devices (electric cookers, electric heaters, LPG stove, incandescent lamp, CFL, LED, fan, TV, refrigerator) are created in the demand tree structure. Electricity is used for lighting, cooking, space heating, water heating, and 
other devices such as fans, TV, and refrigerator if available. Besides electricity, other energy sources are LPG, kerosene, and fuelwood.

Data sources and assumptions

In general, the data required to conduct the analysis are scarce for Bhutan. The data are collected mainly from Bhutan Living Standard Survey Report 2007 and Bhutan Living Standard Survey Report 2017. Using data from the survey reports, in the reference scenario, the growth rate of different energy sources and appliances has been taken from the average growth rate per year between 2007 and 2017.

Despite data availability for the study area being challenging, this is not used to argue against modeling. Instead, it is believed that the modeling process itself instigates the process of identifying and addressing data gaps (Proença and Aubyn, 2009). Modeling is a very data-intensive process, and the data limitations in lowincome and developing countries like Bhutan are a real limitation. Therefore, to address this problem, the LEAP model is used for the analysis because it is easy to use, flexible with data inputs, and can work with fewer data.

\section{Results}

Final energy consumption in the base year (2018) for all end-uses was about $998 \mathrm{GWh}$ as shown in Fig. 1.

Energy demand is broken down by all energy enduses under the reference scenario, and the efficient scenario is given in Figs. 2 and 3, respectively. Figure 2 shows that, at present, space heating is responsible for the highest share of final energy consumption and is further expected to grow in the future in the reference scenario. Overall, in 2040, space heating, cooking, lighting, water heating, and appliances will be responsible for $44 \%, 28 \%, 6 \%, 12$, and $10 \%$ of final energy consumption, respectively.

As reflected in Fig. 3, energy demand in the efficient scenario is offset by fuel switching from wood to electricity. Therefore, space heating energy demand decreases compared to the base year, from 333 to 246 $\mathrm{GWh}$ in 2040. Figure 3 shows that there is an increase in energy demand in appliances. This is because, with an increase in income, households purchase larger appliances that consume more energy.
Over the study period, the energy demand is expected to increase by roughly 1.8 times in the reference scenario whereas it is lesser than the base year in the efficient scenario with increased energy services. In 2040, the energy demand in the reference scenario (1774 GWh) will be about 2 times larger than the energy demand in the efficient scenario $(830 \mathrm{GWh})$.

For lighting, incandescent, fluorescent, CFL, and LED bulbs and tube lights are used. A household uses one or more types of such bulbs for lighting. The primary research found that currently, $57 \%$ of households use incandescent bulbs, $62 \%$ of households use fluorescent tubes, $52 \%$ of households use CFL, and $22 \%$ of households use LED. In the reference scenario, it is expected that despite some effort put by the Department of Renewable Energy to replace incandescent with LED, $10 \%$ of households will still be using incandescent bulbs in 2040. For example, according to an article in Bhutan Times, the Department of Renewable Energy sold 26,500 LED bulbs to replace incandescent bulbs at subsidized rates (LED bulbs to save energy and money, 2016). However, the subsidy was only for a short time, and many households still use inefficient incandescent bulbs. In the efficient scenario, incandescent lamps are completely phased out by 2025 , and LED constitute a $90 \%$ share of the total lighting end-use in 2040. It is found that LED lighting can be more energy efficient than any other known lighting technology (EERE, 2019).

Calibration in the base year Electricity demand for Bhutan in the base year comes to $1567 \mathrm{kWh}$ per household. According to Bhutan Energy Data Directory 2015, the residential sector's electricity consumption amounts to $212 \mathrm{GWh}$, which is about $1292 \mathrm{kWh}$ per year per household (DOE, 2015). The increase in electricity consumption could be because, over the years, there was an increase in population growth and an increase in appliances used.

Figure 4 presents the final energy consumption by energy sources in the reference scenario. In 2018, it comprised $52.5 \%$ wood, $30.5 \%$ electricity, $1 \%$ kerosene, and $15.2 \%$ LPG. The highest percentage of energy sources is from wood. Fuelwood is mainly used for space heating and cooking.

Space heating For space heating in winter (3-4 months), different heating systems used are: electric heater, kerosene, gas heater, and wood fuel. The majority of households use only one type of heating 
Fig. 1 Final energy demand in the current scenario by end-uses
Energy Demand Final Units

Current Scenario, All Fuels

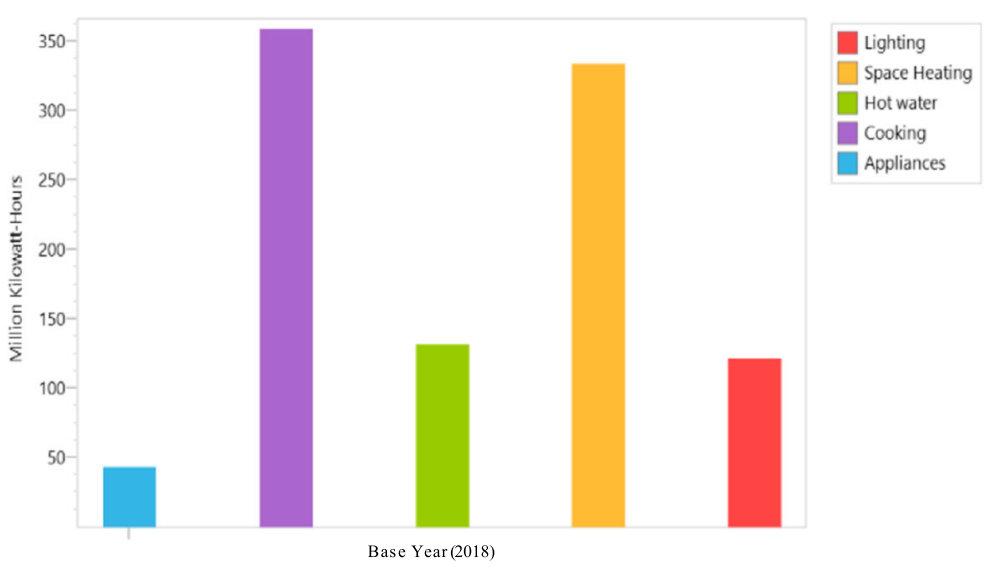

system. However, some districts are at a lower altitude and do not require space heating in winter. In the base year, $24.2 \%$ of the households use an electric heater which consumes $675 \mathrm{kWh}$ per annum, $1.9 \%$ of the households use kerosene heaters which consume 3151 of kerosene per year, and $43.8 \%$ use wood fuel which consumes $1425 \mathrm{~kg}$ of wood (primary research). Bhukhari and thab (oven) are clubbed under wood fuel. Most households outside urban centers use wood fuel for space heating. However, in the reference scenario, calculating the trend from 2007 to 2017, there is an increase of $1.4 \%$ per annum (NSB, 2017). For space heating, electric heater, kerosene heater, and bhukhari (fuelwood) are commonly used. The use of electric heater increased by $1.1 \%$ per year, kerosene heater increased by $0.07 \%$, and bhukhari (fuelwood) increased by $0.01 \%$ (NSB, 2017). As the number of hours used for heating increases, annual energy intensity also increases. The electric heater's annual energy intensity is $1296 \mathrm{kWh}$, kerosene is $450 \mathrm{l}$, and wood is $1800 \mathrm{~kg}$. The final energy consumption reaches about $683 \mathrm{GWh}$ for electric heaters and 63 and 2457 thousand gigajoules for kerosene and wood, respectively, in 2040 .

\section{Energy Demand Final Units \\ Reference Scenario, All fuels}

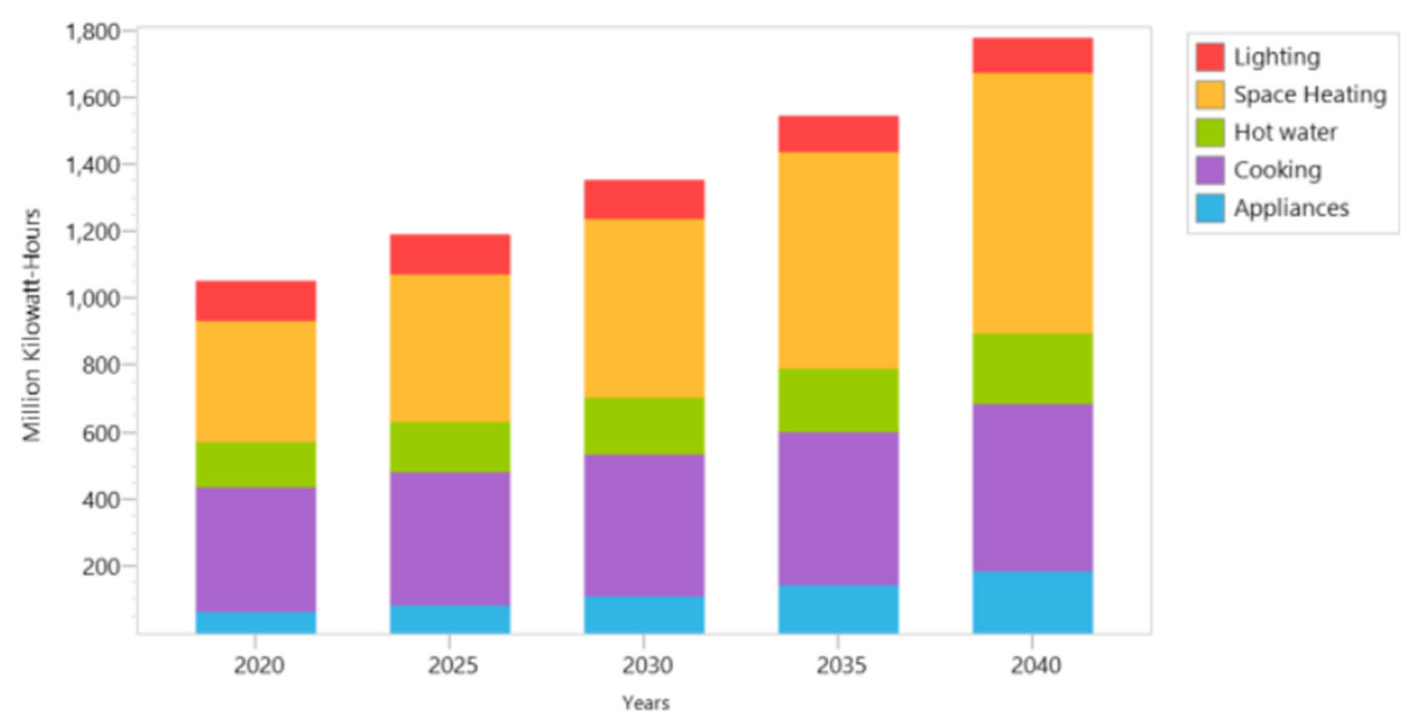

Fig. 2 Final energy demand in the reference scenario by end-uses 


\section{Energy Demand Final Units}

Scenario: Efficient Scenario, All Fuels

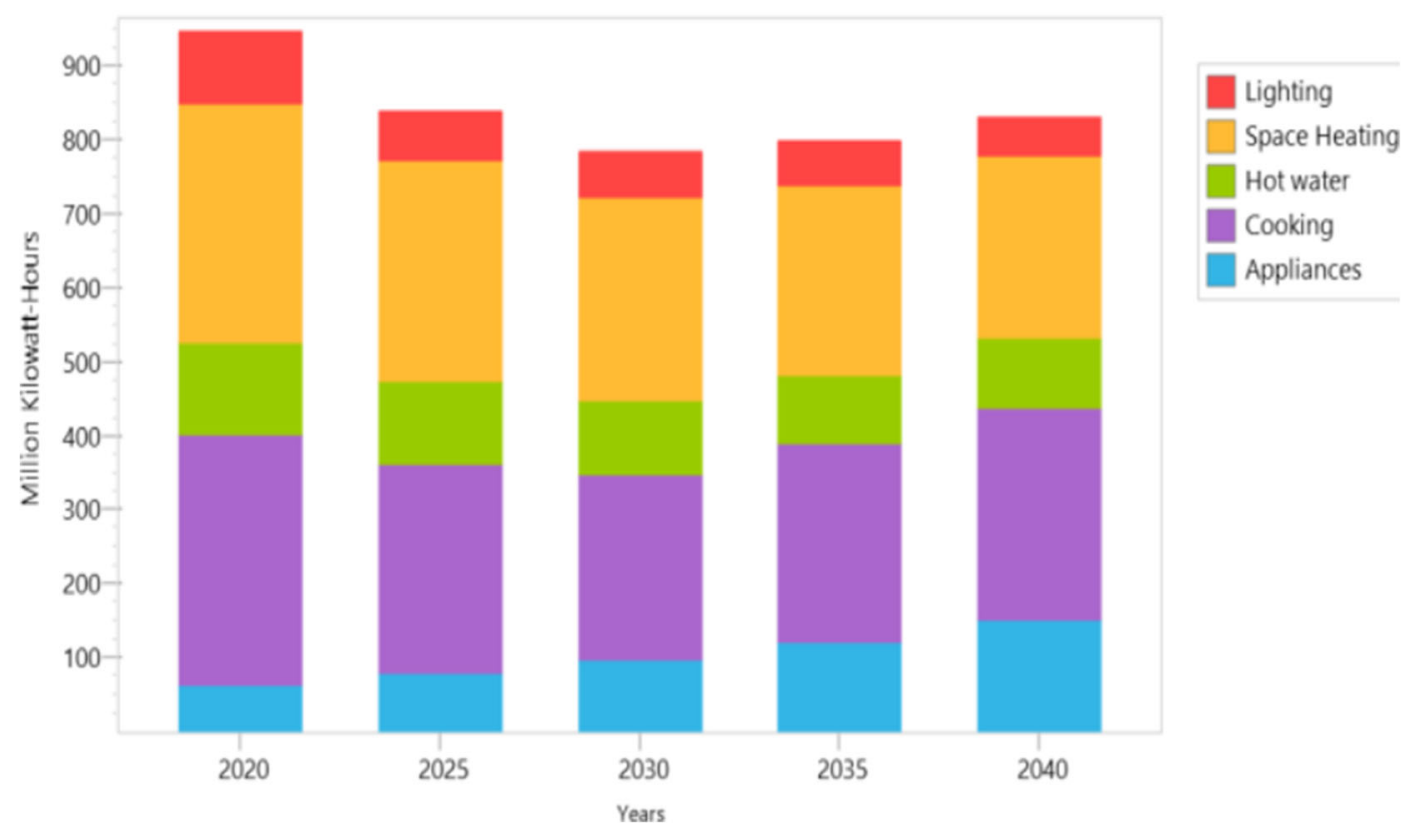

Fig. 3 Final energy demand in the efficient scenario by end-uses

Cooking For cooking, six different energy sources are used. These are electricity, LPG, wood fuel, kerosene, dung cake, and biogas. However, most households use both electricity and LPG for cooking. In the base year, $94.9 \%$ of the households use electricity, $71 \%$ LPG, $21.7 \%$ wood fuel, and less than $1 \%$ use kerosene, dung cake, and biogas (NSB, 2017). As the percentage of households using kerosene, dung cake, and biogas is very small, this calculation is not done in the study. The annual energy intensity of electricity is $383 \mathrm{kWh}$ per household and $96 \mathrm{~kg}$ of LPG per annum. However, in the reference scenario, calculating the trend from 2007 to 2017 , there is an increase of $6.06 \%$ of households using electricity for cooking per annum, an increase of 4.84\% of households using LPG per year, and households using wood for cooking decreased by $1.9 \%$ per annum (NSB, 2017). As there is not a drastic change in household size final energy intensity for electricity and LPG would remain the same as current year. That is, $383 \mathrm{kWh}$ for using electricity and $96 \mathrm{~kg}$ of LPG. However, as households shift towards using electricity and LPG for cooking most meals, the amount of wood used would decrease. Thus, the annual energy intensity would be $780 \mathrm{~kg}$. The final energy intensity is 101 million $\mathrm{kWh}, 270$ million $\mathrm{kWh}, 128 \mathrm{GWh}$ for electricity, LPG, and wood, respectively.

Figure 5 represents final energy consumption by energy sources in the efficient scenario. Due to the use of more efficient electric cookers and heaters, a fuel switch will take place for cooking and heating nevertheless more pronounced in the efficient scenario compared to the reference scenario. The percentage of energy sources in the efficient scenario by 2040 will be $60.8 \%$ electricity, $22.4 \%$ LPG, and $16.8 \%$ wood. The decrease in the percentage of wood and the increase in electricity consumption is mainly from switching from wood to electricity for space heating and cooking.

Space heating In the efficient scenario, it is expected that by $2040,60 \%$ use electricity for space heating and to phase out kerosene. The percentage of households using wood is also expected to decrease to $15 \%$. The final energy consumption is about $130 \mathrm{GWh}$ and 116 million $\mathrm{kWh}$ for electricity and wood fuel.

Cooking It is expected that by 2020, $100 \%$ of households would use electricity for cooking. The final energy consumption is 101 million $\mathrm{kWh}$. The percentage of 


\section{Energy Demand Final Units}

Scenario: Ref

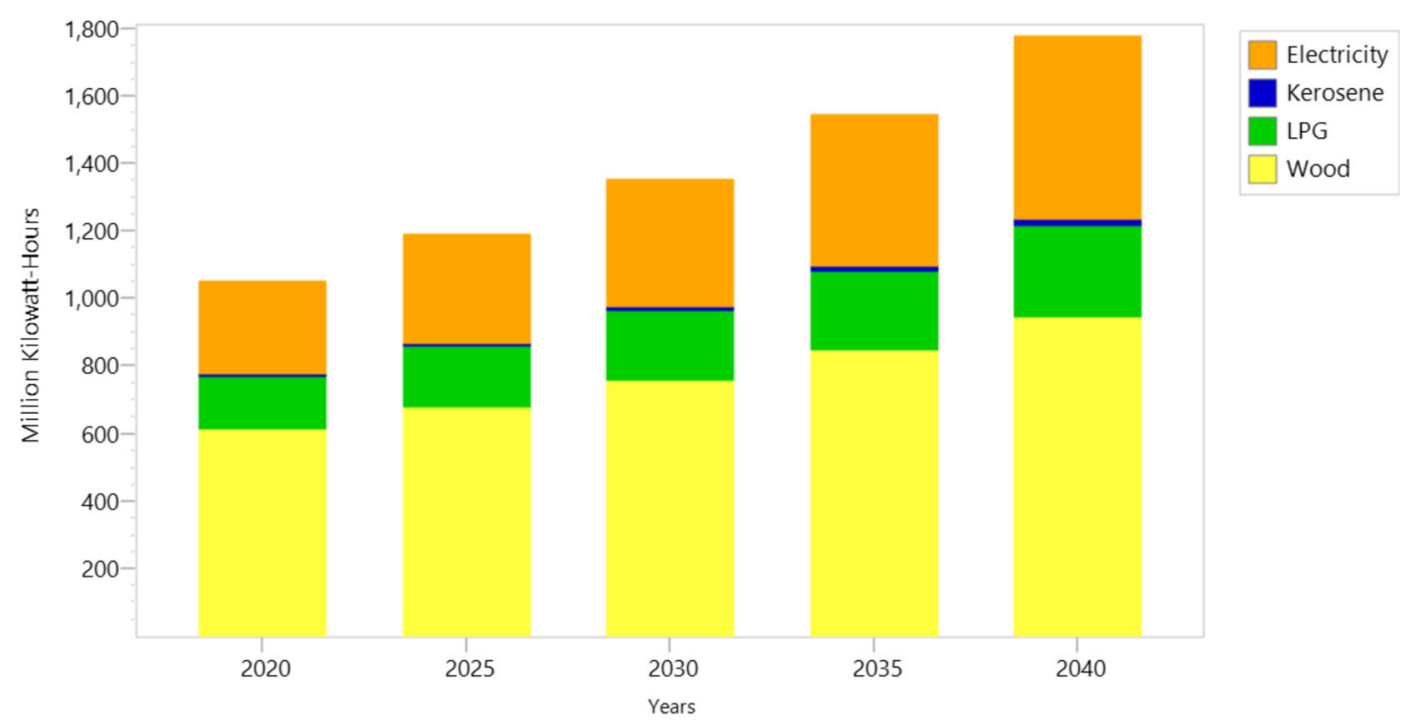

Fig. 4 Final energy consumption by energy sources in the reference scenario

LPG is expected to decrease as the use of electricity increases. The final energy consumption for LPG is 185 million kWh. By 2030, it is expected that wood for cooking would be phased out, and by 2029 annual energy intensity for wood is expected to be $520 \mathrm{~kg}$.

Energy savings from all end-uses in 2040 by transitioning energy use to the efficient scenario is 830 GWh, as shown in Fig. 6. Overall, about 53\% of energy savings can be achieved in 2040 from all end-uses and energy sources. It is striking that about $35 \%$ of total energy savings come from fuel switching in cooking and $30 \%, 6 \%, 11 \%$, and $18 \%$ energy savings from space heating, lighting, hot water heating, and appliances, respectively. This reflects the importance of cooking and space heating end-uses in the years to come. In 2040, final energy consumption from appliances enduse (fan, television, and refrigerator) will be around $151 \mathrm{GWh}$, which is a little lower than the reference scenario (185 GWh). Energy consumption from refrigerators $(132 \mathrm{GWh})$ is more than energy consumption from fans and TV (6 GWh, $36 \mathrm{GWh})$ together in 2040. Appliances energy consumption is increasing rapidly even in the efficient scenario by about 2.6 times in 2040 compared to 2018 (58GWh).

\section{Discussion}

The aim is achieved by estimating Bhutan's final energy saving in 2040 by realizing that the efficient scenario is 830 million $\mathrm{kWh}$. Overall, the results suggest that 53\% final energy saving can be achieved in 2040 from all end-uses and energy sources compared to the reference scenario. Cumulatively, $38 \%$ of final energy savings (19 TWh) can be achieved in the study period (2018-2040) from the efficient scenario while all basic energy needs are fully met in 2040

Energy savings can be mainly achieved by shifting fuel for cooking and space heating from wood to electricity since electricity generation in Bhutan is from a renewable source with almost $100 \%$ generation from hydropower (NEC, 2015) as the results suggest that $35 \%$ of the total energy savings come from fuel switching in cooking and $30 \%$ of savings from space heating; the greatest intervention can be to switch towards electric stoves and electric heaters. Other studies also found that in the residential sector, space heating is expected to provide the largest opportunity for energy savings in the home (McNeil et al., 2008). 


\section{Energy Demand Final Units \\ Efficient scenario}

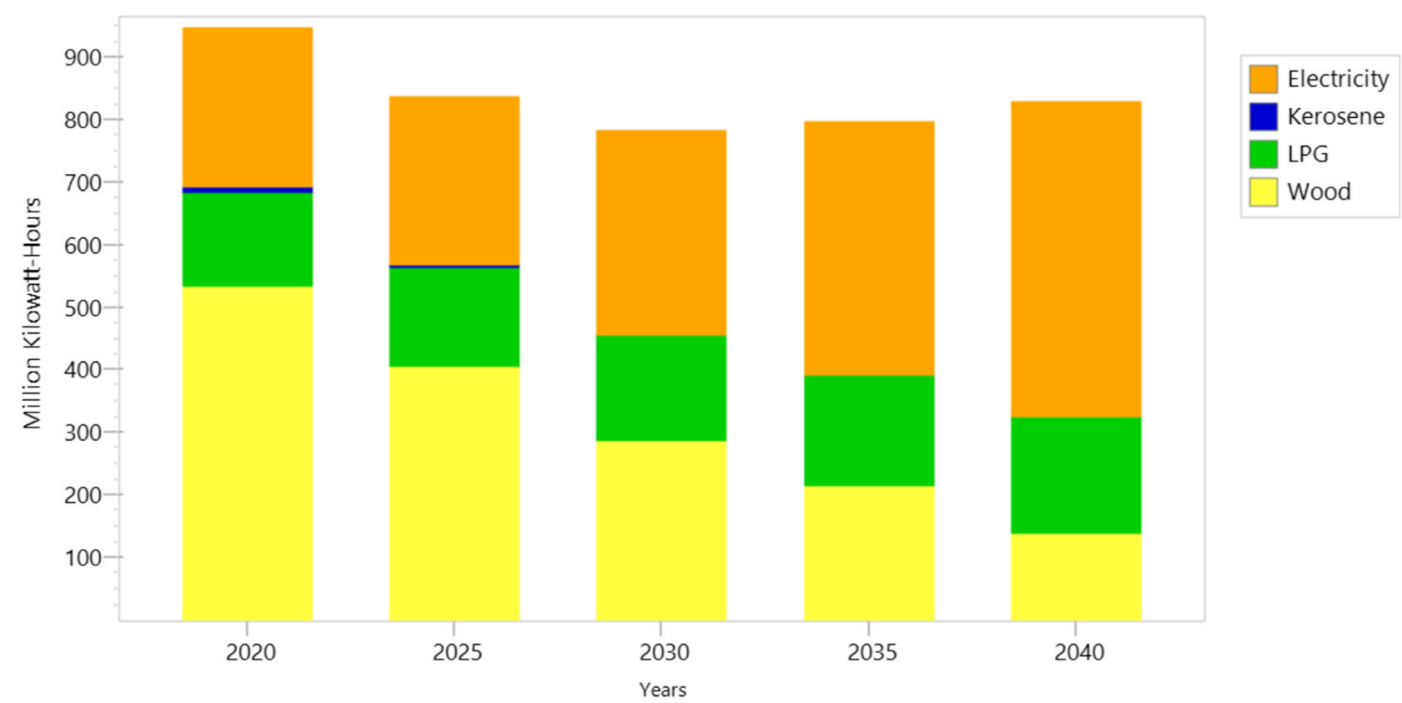

Fig. 5 Final energy consumption by energy sources in the efficient scenario

An entry point can be to start large projects to introduce subsidized electric stove and electric heaters in the residential sector to implement the Nationally Determined Contributions (NDCs). One of the nine mitigation strategies mentioned in the 1st NDC implemented from 2020 to 2025 is Energy demand-side management by promoting energy efficiency in appliances, buildings, and industrial processes and technologies (NEC, 2015). Implementing energy efficiency interventions in the building sector such as Standards and Labeling ( $\mathrm{S} \& \mathrm{~L}$ ), EE building codes, energy audit and reporting, and energy efficiency and conservation aspect of public procurement system

\section{Final Energy Savings}

Efficient Scenario Avoided vs Reference Scenario

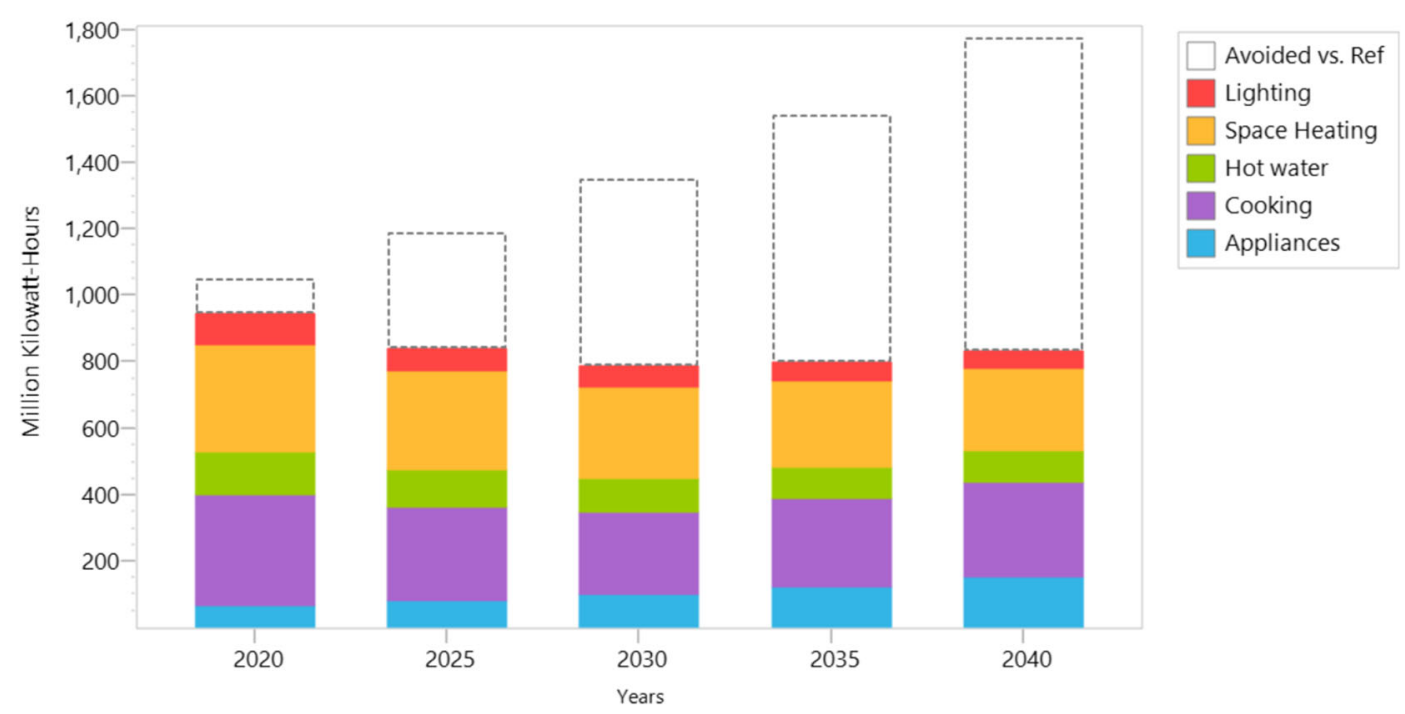

Fig. 6 Final energy savings from realizing the efficient scenario 
mentioned in the Energy Efficiency Roadmap (DRE, 2019) would greatly help in enhancing energy efficiency.

Another recommendation would be to create awareness among the people to shift to electricity from wood for cooking and heating. This will not only save energy but also help in reducing deforestation and forest degradation. Simultaneously, it will reduce indoor air pollution caused by traditional cooking and space heating which constitutes a major health risk. Thus, strategies to reduce fuelwood consumption have co-benefits of mitigating climate change, conserving forests, and improving human livelihoods (Dresen et al., 2014).

It would be good to set a target year to phase out incandescent bulb as it is very inefficient and a high percentage (57\%) of households still use them. This can be done by providing subsidized LED bulbs and creating awareness on the benefit of using energy-efficient bulbs. Studies found that the replacement of incandescent light bulbs with more energy-efficient lighting sources like CFL or LED is environmentally friendly and durable (Mills and Schleich, 2014; Muneeb, 2017).

While major energy savings can be made in cooking, space, and water heating by shifting to electricity, appliance energy consumption is increasing rapidly even in the efficient scenario by about 2.6 times in 2040 compared to 2018. With an increase in income, households purchase larger appliances that consume more energy which is widely discussed in the rebound effect literature (Chakravarty et al., 2013; Kipouros, 2018; McNeil and Leventis, 2015). Also, as the energy source of appliances is electricity, there is not a shift of energy source. Thus, energy saving from appliances in the efficient scenario is less compared to cooking, water heating, and space heating, which require a change from wood fuel to electricity. Shifting from wood fuel to electricity would increase the electricity demand, which the country can meet. Bhutan has a theoretical hydropower potential of $30,000 \mathrm{MW}$, out of which 23,765 MW is techno-economically feasible (NEC, 2016). Bhutan's Alternative Renewable Energy Policy, 2013 aims to promote alternative sources, including solar power plants (photovoltaic and thermal), smallscale hydropower, geothermal plants, wind turbines and windmills, biomass, and biogas plants. Bhutan has established a preliminary minimum goal of 20 megawatts (MW) of renewable energy produced by 2025 through a mix of renewable energy technologies (MoEA, 2013).
It is striking that about $35 \%$ of total energy savings come from fuel switching in cooking and 30\%, 6\%, $11 \%$, and $18 \%$ energy savings from space heating, lighting, hot water heating, and appliances, respectively.

Fuel switching to an energy-efficient system would also reduce deforestation and biodiversity loss which are considered key drivers of zoonotic disease emergence, such as SARS, MERS, and now COVID-19 (Malla, 2013; Khetan, 2020). Achieving energy efficiency among residential households could also improve the physical environment and health, greater earning capacity, increased disposable income, and hence generate development co-benefits (Gupta, 2017; Wilkinson et al., 2007). For example, shifting from inefficient wood fuel to electricity would save energy and reduce health risks from smoke and the collection of firewood.

\section{Conclusion and recommendation}

The study estimated the final energy demand savings of the residential sector in Bhutan by transitioning to efficient energy technology until 2040. The research goal is to determine how much total energy savings can be made by transitioning to efficient energy systems. The long-range Energy Alternatives Planning System (LEAP) model is used to forecast activity level, final demand, and energy savings. The scenarios used are a reference and efficient. Although households meet the basic level of energy services fully in 2040, it is met by inefficient appliances in the reference scenario. In the efficient scenario, the basic needs of energy are fully met in 2040 using efficient appliances. The study found that energy savings in 2040 by transitioning energy use to the efficient scenario are $830 \mathrm{GWh}$. Major energy saving is from switching from wood fuel to electricity for cooking, space heating, and water heating. Reducing greenhouse gases has both local and global benefits, thus, contributing towards achieving climate goals such as the Paris agreement.

The results suggest policy recommendations for shifting to an energy-efficient system mainly from fuelwood to electricity in cooking and space heating. This type of study can also be replicated in other countries to recommend policy-makers to make evidence-based decisions for the environment and human health. Another recommendation would be if future research can be 
done in this field, including calculating emissions and cost-benefit analysis. Thus, this study could be the ground for further research.

Acknowledgements The authors express our sincere gratitude to all the individuals who supported us for the successful completion of the study. Our heartfelt gratitude also goes to Asian University for Women for funding as a part of Senior Thesis without which this study would not have been possible. We express our profound thanks to all the survey participants and to the National Statistical Bureau for providing secondary data. Lastly, we are thankful to the reviewers for your valuable comments that have significantly improved the paper.

\section{Declarations}

Conflict of interest The authors declare no competing interest.

\section{Annexure}

Table 1 Unit level assumptions and data sources for appliances in the base year

\begin{tabular}{|c|c|c|c|}
\hline Appliances & $\begin{array}{l}\text { Technology/ } \\
\text { efficiency }\end{array}$ & $\begin{array}{l}\text { Diffusion in } \\
\text { the base year } \\
(\%)\end{array}$ & $\begin{array}{l}(\mathrm{kWh} / \\
\mathrm{yr})\end{array}$ \\
\hline $\begin{array}{l}\text { Incandescent ( } 5 \mathrm{~h} / \text { day, } \\
365 \text { days/yr, three } \\
\text { lamps/households })\end{array}$ & $100 \mathrm{~W}$ & $\begin{array}{l}57 \% \\
\text { saturation }\end{array}$ & 548 \\
\hline $\begin{array}{l}\text { Fluorescent ( } 5 \mathrm{~h} / \text { day, } \\
365 \text { days/yr, five } \\
\text { lamps/households) }\end{array}$ & $40 \mathrm{~W}$ & $\begin{array}{l}62 \% \\
\text { saturation }\end{array}$ & 365 \\
\hline $\begin{array}{l}\text { CFL ( } 5 \text { h/day, } 365 \text { days/yr, } \\
\text { five lamps/households) }\end{array}$ & $30 \mathrm{~W}$ & $\begin{array}{l}52 \% \\
\quad \text { saturation }\end{array}$ & 274 \\
\hline $\begin{array}{l}\text { LED ( } 5 \mathrm{~h} / \text { day, } 365 \text { days/h, } \\
\text { five lamps/households) }\end{array}$ & $18 \mathrm{~W}$ & $\begin{array}{l}22 \% \\
\text { saturation }\end{array}$ & 164 \\
\hline $\begin{array}{l}\text { Fan (6h/day, } 90 \text { days/yr, } 2 \\
\text { fans/households) }\end{array}$ & $70 \mathrm{~W}$ & $\begin{array}{l}15 \% \\
\text { saturation }\end{array}$ & 76 \\
\hline $\begin{array}{l}\text { TV (4h/day, } 365 \text { days/yr, } 1 \\
\text { TV/households) }\end{array}$ & $55 \mathrm{~W}$ & $\begin{array}{l}70 \% \\
\text { saturation }\end{array}$ & 80 \\
\hline $\begin{array}{l}\text { Space heating (electric } \\
\text { heater) }(5 \mathrm{~h} / \text { day, } \\
\text { 90days/yr, } 1 \\
\text { heater/households })\end{array}$ & $1500 \mathrm{~W}$ & $\begin{array}{l}24.2 \% \\
\quad \text { saturation }\end{array}$ & 675 \\
\hline $\begin{array}{l}\text { Electric water heater } \\
(2 \mathrm{~h} / \text { week, } 52 \text { weeks/day, } \\
1 \text { electric water heater } \\
\text { per year })\end{array}$ & $1500 \mathrm{~W}$ & $\begin{array}{l}63 \% \\
\text { saturation }\end{array}$ & 156 \\
\hline
\end{tabular}

Table 2 Unit level assumptions for cooking in the base year

\begin{tabular}{lll}
\hline & $\begin{array}{l}\text { Diffusion (\%) in } \\
\text { the base year }\end{array}$ & $\begin{array}{l}\text { Annual energy } \\
\text { intensity/household }\end{array}$ \\
\hline Electric cooker & $94.9 \%$ saturation & $383 \mathrm{kWh}$ \\
LPG stove & $71 \%$ saturation & $96 \mathrm{~kg}$ \\
Fuelwood & $21.7 \%$ saturation & $1000 \mathrm{~kg}$ \\
\hline
\end{tabular}

Table 3 A summary assumptions and reference technology are given for appliances in the below table

\begin{tabular}{|c|c|c|c|}
\hline Appliances & $\begin{array}{l}\text { Technology/ } \\
\text { efficiency }\end{array}$ & $\begin{array}{l}\text { Diffusion } \\
\text { in } 2040\end{array}$ & $\begin{array}{l}(\mathrm{kWh} / \\
\mathrm{yr})\end{array}$ \\
\hline $\begin{array}{l}\text { Incandescent (6 h/day, } 365 \\
\text { days/yr, two } \\
\text { lamps/households) }\end{array}$ & $100 \mathrm{~W}$ & $\begin{array}{l}10 \% \\
\text { satura- } \\
\text { tion }\end{array}$ & 438 \\
\hline $\begin{array}{l}\text { Fluorescent (6h/day, } 365 \\
\text { days/yr, four } \\
\text { lamps/households) }\end{array}$ & $36 \mathrm{~W}$ & $\begin{array}{l}20 \% \\
\text { satura- } \\
\text { tion }\end{array}$ & 315 \\
\hline $\begin{array}{l}\text { CFL (6 h/day, } 365 \text { days/yr, } \\
\text { seven lamps/households) }\end{array}$ & $20 \mathrm{~W}$ & $\begin{array}{l}30 \% \\
\text { satura- } \\
\text { tion }\end{array}$ & 307 \\
\hline $\begin{array}{l}\text { LED ( } 7 \text { h/day, } 365 \text { days/h, } \\
\text { seven lamps/households) }\end{array}$ & $15 \mathrm{~W}$ & $\begin{array}{l}65 \% \\
\text { satura- } \\
\text { tion }\end{array}$ & 268 \\
\hline $\begin{array}{l}\text { Fan ( } 8 \mathrm{~h} / \text { day, } 100 \text { days/yr, } 3 \\
\text { fans/households) }\end{array}$ & $70 \mathrm{~W}$ & $\begin{array}{l}50 \% \\
\text { satura- } \\
\text { tion }\end{array}$ & 168 \\
\hline $\begin{array}{l}\text { TV (5h/day, } 365 \text { days/yr, } 1 \\
\text { TV/households) }\end{array}$ & $100 \mathrm{~W}$ & $100 \%$ & 183 \\
\hline $\begin{array}{l}\text { Space heating (electric heater) } \\
\text { (6 h/day, 90days/yr, } 2 \\
\text { heater/households) }\end{array}$ & $1200 \mathrm{~W}$ & $\begin{array}{l}40 \% \\
\text { satura- } \\
\text { tion }\end{array}$ & 1296 \\
\hline $\begin{array}{l}\text { Electric water heater ( } 3 \\
\text { h/week, } 52 \text { weeks/day, } 2 \\
\text { electric water heater per } \\
\text { year) }\end{array}$ & $2000 \mathrm{~W}$ & $\begin{array}{l}80 \% \\
\text { satura- } \\
\text { tion }\end{array}$ & 624 \\
\hline
\end{tabular}

Table 4 Assumptions, reference technology for cooking

\begin{tabular}{lll}
\hline End-uses & Diffusion in 2040 (\%) & $\begin{array}{l}\text { Annual energy } \\
\text { intensity/household }\end{array}$ \\
\hline Electric cooker & $100 \%$ saturation & $378 \mathrm{kwh}$ \\
LPG stove & $80 \%$ saturation & $96 \mathrm{~kg}$ \\
Fuelwood & Growth $(-1.9 \%)$ & $780 \mathrm{~kg}$ \\
\hline
\end{tabular}


Table 5 A summary assumptions, efficient technology, and efficient are given for appliances in the below

\begin{tabular}{|c|c|c|c|}
\hline Appliances & Technology/efficiency & Diffusion in $2040(\%)$ & $(\mathrm{kWh} / \mathrm{yr})$ \\
\hline Incandescent (6 h/day, 365 days/yr, one lamp/households) & $100 \mathrm{~W}$ & $0 \%$ & 219 \\
\hline Fluorescent (6h/day, 365days/yr, four lamps/households) & $36 \mathrm{~W}$ & $10 \%$ saturation & 315 \\
\hline CFL (6 h/day, 365 days/yr, seven lamps/households) & $15 \mathrm{~W}$ & $15 \%$ saturation & 230 \\
\hline LED (6h/day, 365 days/h, seven lamps/households) & $9 \mathrm{~W}$ & $90 \%$ saturation & 138 \\
\hline Fan (8 h/day, 100 days/yr, 3 fans/households) & $70 \mathrm{~W}$ & $13 \%$ saturation & 168 \\
\hline TV (5 h/day, 365 days/yr, 1 TV/households) & $80 \mathrm{~W}$ & $100 \%$ & 146 \\
\hline Space heating (electric heater) (6 h/day, 90days/yr, 2 heater/households) & $1000 \mathrm{~W}$ & $60 \%$ saturation & 1080 \\
\hline Electric water heater ( $3 \mathrm{~h} /$ week, 52 weeks/day, 2 electric water heater per year) & $1500 \mathrm{~W}$ & $80 \%$ saturation & 468 \\
\hline
\end{tabular}

Table 6 Assumptions, efficient technology, and efficient for cooking

\begin{tabular}{lll}
\hline End-uses & Diffusion in 2040 (\%) & $\begin{array}{l}\text { Annual energy } \\
\text { intensity/household }\end{array}$ \\
\hline Electricity & $100 \%$ saturation & $378 \mathrm{kWh}$ \\
LPG stove & $55 \%$ saturation & $96 \mathrm{~kg}$ \\
Fuelwood & $0 \%$ saturation & $520 \mathrm{~kg}$ \\
\hline
\end{tabular}

Table 7 Energy consumption in the reference scenario in Billion $\mathrm{kWh}$ (in the selected years)

\begin{tabular}{llllll}
\hline End-uses & 2020 & 2025 & 2030 & 2035 & 2040 \\
\hline Lighting & 0.1 & 0.1 & 0.1 & 0.1 & 0.1 \\
Space heating & 0.4 & 0.4 & 0.5 & 0.6 & 0.8 \\
Hot water & 0.1 & 0.2 & 0.2 & 0.2 & 0.2 \\
Cooking & 0.4 & 0.4 & 0.4 & 0.5 & 0.5 \\
Appliances & 0.1 & 0.1 & 0.1 & 0.1 & 0.2 \\
Total & 1.1 & 1.2 & 1.3 & 1.5 & 1.8 \\
\hline
\end{tabular}

Table 8 Energy consumption in the efficient scenario in Billion $\mathrm{kWh}$ (in the selected years)

\begin{tabular}{lccccc}
\hline End-uses & 2020 & 2025 & 2030 & 2035 & 2040 \\
\hline Lighting & 0.1 & 0.1 & 0.1 & 0.1 & 0.1 \\
Space heating & 0.3 & 0.3 & 0.3 & 0.3 & 0.2 \\
Hot water & 0.1 & 0.1 & 0.1 & 0.1 & 0.1 \\
Cooking & 0.3 & 0.3 & 0.2 & 0.3 & 0.3 \\
Appliances & 0.1 & 0.1 & 0.1 & 0.1 & 0.2 \\
Total & 0.9 & 0.8 & 0.8 & 0.8 & 0.8 \\
\hline
\end{tabular}




\section{References}

Bhattacharya, \& Timilsina. (2009). Energy demand models for policy formulation: a comparative study of energy demand models. The World Bank Policy Research Working Paper WPS, 4866.

Chakravarty, D., Dasgupta, S., \& Roy, J. (2013). Rebound effect: how much to worry? Current Opinion in Environmental Sustainability, 5(2), 216-228.

Chen, R., Rao, Z. H., \& Liao, S. M. (2019). Hybrid LEAP modeling method for long-term energy demand forecasting of regions with limited statistical data. Journal of Central South University, 26(8), 2136-2148.

Department of Energy (DOE). (2015). Bhutan Energy Data Directory 2015. Ministry of Economic Affairs, Royal Government of Bhutan, Thimphu.

Department of Renewable Energy (DRE). (2019). Energy efficiency roadmap. Royal Government of Bhutan, Thimphu: Ministry of Economic Affairs.

Dresen, E., DeVries, B., Herold, M., Verchot, L., \& Müller, R. (2014). Fuelwood savings and carbon emission reductions by the use of improved cooking stoves in an Afromontane Forest, Ethiopia. Land, 3(3), 1137-1157.

Duan, H., Zhang, S., Duan, S., Zhang, W., Duan, Z., Wang, S., \& Wang, X. E. (2019). Carbon emissions peak prediction and the reduction pathway in buildings during operation in Jilin Province based on LEAP. Sustainability, 11(17), 4540.

Emodi, N. V., Emodi, C. C., Murthy, G. P., \& Emodi, A. S. A. (2017). Energy policy for low carbon development in Nigeria: a LEAP model application. Renewable and Sustainable Energy Reviews, 68, 247-261.

Gupta, M. (2017). Clean and efficient energy systems in slums transformation: the case of South Asia and Sub-Saharan Africa, Doctoral dissertation. Budapest: Department of Environmental Sciences and Policy, Central European University.

IRENA. (2019). Renewables Readiness Assessment Kingdom of Bhutan.

Kipouros, P. (2018). Energy efficiency and the rebound effect in developing countries. University of Surrey: Doctoral dissertation.

Khetan, A. K. (2020). COVID-19: why declining biodiversity puts us at greater risk for emerging infectious diseases, and what we can do. Journal of General Internal Medicine, 1-2.

LEAP. (2018, 27 October). Retrieved from https://www. energycommunity.org/

LED bulbs to save energy and money. (2016, 7 February). Bhutan Times. Retrieved from https://www.pressreader. com/bhutan/bhutantimes/20160207/281573764738347

Lhendup, T., Lhundup, S., \& Wangchuk, T. (2010). Domestic energy consumption patterns in urban Bhutan. Energy for Sustainable Development, 14(2), 134-142.

Malla, S. (2013). Household energy consumption patterns and its environmental implications: assessment of energy access and poverty in Nepal. Energy Policy, 61, 990-1002.

McNeil, M. A., McNeil, M. A., \& Letschert, V. (2008). Global potential of energy efficiency standards and labeling programs (No. LBNL-760E). Berkeley, CA (United States): Lawrence Berkeley National Lab (LBNL).
McNeil, M. A., \& Leventis, G. (2015). Rebound effects in the context of developing country efficiency Programs

Mills, B., \& Schleich, J. (2014). Household transition to energy efficient lighting. Energy Economics, 46, 151-160.

Ministry of Economic Affairs (MoEA). (2013). Alternative renewable energy policy 2013. Thimphu: Royal Government of Bhutan.

Mirjat, N. H., Uqaili, M. A., Harijan, K., Walasai, G. D., Mondal, M. A. H., \& Sahin, H. (2018). Long-term electricity demand forecast and supply side scenarios for Pakistan (2015-2050): a LEAP model application for policy analysis. Energy, 165, 512-526.

Moradi, M. A. (2013, June). Developing the electricity demand model for Iran's residential sector; based on LEAP. In In Presented at the 28th Power System Conference, Tehran, Iran.

Muneeb, A. (2017). Research study on gained energy efficiency in a commercial setup by replacing conventional lights with modern energy saving lights. Journal of Architectural Engineering Technology, 6(2), 1-6.

National Environment Commission (NEC). (2016). Bhutan State of the Environment Report 2016. Thimphu: Royal Government of Bhutan.

National Environment Commission (NEC). (2015). Intended Nationally Determined Contribution 2015. Thimphu: Royal Government of Bhutan.

National Statistical Bureau of Bhutan (NSB). (2007). Bhutan Living Standard Survey Report 2017. Thimphu: Royal Government of Bhutan.

National Statistical Bureau of Bhutan (NSB). (2017). Bhutan Living Standard Survey Report 2017. Retrieved from: Royal Government of Bhutan, Thimphu.

Office of Energy Efficiency and Renewable Energy (EERE). (2019). Retrieved from https://www.energy.gov/eere/ssl/ledbasics

Ouedraogo, N. S. (2017). Africa energy future: alternative scenarios and their implications for sustainable development strategies. Energy Policy, 106, 457-471.

Proença, S. A., \& Aubyn, M. S. (2009). A hybrid top-down/ bottom-up model for energy policy analysis in a small open economy-the Portuguese case (52).

Swan, L. G., \& Ugursal, V. I. (2009). Modeling of end-use energy consumption in the residential sector: a review of modeling techniques. Renewable and Sustainable Energy Reviews, 13(8), 1819-1835.

Tshering, S., \& Tamang, B. (2004, October). Hydropower-Key to sustainable, socio-economic development of Bhutan. In United Nations Symposium on Hydropower and Sustainable Development (pp. 27-29)

Urban, F., Benders, R. M. J., \& Moll, H. C. (2007). Modelling energy systems for developing countries. Energy Policy, 35(6), 3473-3482.

Wilkinson, P., Smith, K. R., Beevers, S., Tonne, C., \& Oreszczyn, T. (2007). Energy, energy efficiency, and the built environment. The Lancet, 370(9593), 1175-1187.

Publisher's note Springer Nature remains neutral with regard to jurisdictional claims in published maps and institutional affiliations. 